\section{Yellow Squash and Zucchini Cultivar Selection for Resistance to Cucurbit Leaf Crumple Virus in the Southeastern United States}

\author{
Joara Secchi Candian ${ }^{1}$, Timothy Coolong ${ }^{1}$, Bhabesh Dutta ${ }^{2}$, \\ Rajagopalbabu Srinivasan ${ }^{3}$, Alton Sparks ${ }^{3}$, Apurba Barman $^{3}$, and \\ Andre Luiz Biscaia Ribeiro da Silva ${ }^{1,4}$
}

\begin{abstract}
AdDITIONAL INDEX wORDs. Cucurbita pepo, disease severity, fruit yield and quality, sweetpotato whitefly, weather conditions

SUMMARY. Large populations of sweetpotato whiteflies (Bemisia tabaci) have become more regular occurrences during the fall months in parts of the southeastern United States. Large populations of sweetpotato whiteflies have resulted in a significant increase in the incidence of sweetpotato whitefly-transmitted viruses, particularly the cucurbit leaf crumple virus $(\mathrm{CuLCrV})$, which has the potential to cause complete yield loss of fall-planted yellow squash and zucchini (Cucurbita pepo). This study evaluated commercial cultivars of yellow squash and zucchini for resistance against $\mathrm{CuLCrV}$ and estimated the yield and fruit quality under environmental conditions during the fall growing season in the southeastern United States. A factorial experimental design was conducted with nine yellow squash and 11 zucchini cultivars during Fall 2017, Fall 2018, and Fall 2019 in Tifton, GA. In situ weather stations monitored the weather conditions during growing seasons, and yellow pest monitor cards monitored the sweetpotato whitefly populations in 2018 and 2019.

During all growing seasons, yellow squash and zucchini plants were rated weekly for the severity of CuLCrV. Harvests were conducted 12 times during each season, and fruit were graded as fancy, medium, and culls. Rainfall distribution directly affected the sweetpotato whitefly populations during the production year. In 2018, frequent rainfall events created field conditions that reduced the sweetpotato whitefly populations compared with those during 2017 and 2019. The severity of CuLCrV negatively impacted both the yield and quality of fruit of yellow squash and zucchini, and no resistant commercial cultivars of yellow squash or zucchini were identified. Nonetheless, the yellow squash cultivars Lioness, Gold Prize, and Grand Prize, and the zucchini cultivars SV6009YG and SV0914YG had the highest yields when subjected to the highest sweetpotato whitefly populations during the study.
\end{abstract}

S weetpotato whiteflies (Bemisia tabaci) have been reported in the southeastern United States

Received for publication 14 Apr. 2021. Accepted for publication 1 June 2021.

Published online 9 July 2021.

${ }^{1}$ Department of Horticulture, University of Georgia, 2360 Rainwater Road, Tifton, GA 31793

${ }^{2}$ Department of Plant Pathology, University of Georgia, 2360 Rainwater Road, Tifton, GA 31793

${ }^{3}$ Department of Entomology, University of Georgia, 2360 Rainwater Road, Tifton, GA 31793

${ }^{4}$ Department of Horticulture, Auburn University, 124 Funchess Hall, Auburn, AL 36849

The study was funded by the United States Department of Agriculture Non-Assistance Cooperative Agreement (\#58-6080-9-006 "Managing whiteflies and whitefly-transmitted viruses in vegetable crops in the southeastern U.S.").

A.L.B.R.d.S. is the corresponding author. E-mail: adasilva@auburn.edu.

This is an open access article distributed under the CC BY-NC-ND license (https://creativecommons. org/licenses/by-nc-nd/4.0/).

https://doi.org/10.21273/HORTTECH04877-21 since 1894. However, no economic impact on crops was associated with this pest until 1986, when significant infestations impacted ornamental plant nurseries in Florida (Price et al., 1987). Most recently, the sweetpotato whitefly population has increased in the southeastern United States during the fall months. This is particularly notable in northwest Florida, southwest Georgia, and southeast Alabama, where the growing seasons of cucurbit vegetables [e.g., yellow squash and zucchini (Cucurbita pepo), cucumber (Cucumis sativus)] and agronomic crops [e.g., cotton (Gossypium hirsutum)] overlap during the year, allowing for the insect to disperse easily across crops. Consequently, vegetable growers have been challenged with sweetpotato whitefly-transmitted viruses, particularly the cucurbit leaf crumple virus (CuLCrV), which has caused significant yield losses of yellow squash and zucchini (Cucurbita pepo) crops (Akad et al., 2008; Coolong, 2017; Nyoike et al., 2008; Webb et al., 2017).

Georgia is a significant producer of yellow squash and zucchini in the United States (U.S. Department of Agriculture, 2019), with more than 7000 acres planted during the spring and fall seasons (Wolfe and Stubbs, 2018). When planted in the spring, yellow squash and zucchini have low to no damage from whiteflies because the insect populations are low. However, when yellow squash and zucchini are planted in the fall, there is an overwhelming increase in the sweetpotato whitefly populations and CuLCrV infection, resulting in significant yield losses (Gautam et al., 2020; Nyoike et al., 2008). Symptoms of CuLCrV exhibited by yellow squash and zucchini plants include severe foliar chlorosis, curling, stunting, and green streaking of the fruit, rendering them unmarketable (Webb et al., 2017). Between 2016 and 2017, growers in Georgia estimated losses of more than $\$ 50$ million, primarily because of disease outbreaks caused by whitefly-transmitted virus complex (Little, 2019).

During CuLCrV acquisition, there is a latent period that allows for

\begin{tabular}{llll}
\hline $\begin{array}{l}\text { Units } \\
\begin{array}{l}\text { To convert U.S. to SI, } \\
\text { multiply by }\end{array}\end{array}$ & U.S. unit & SI unit & $\begin{array}{l}\text { To convert SI to U.S., } \\
\text { multiply by }\end{array}$ \\
\hline 0.4047 & acre $(\mathrm{s})$ & $\mathrm{ha}$ & 2.4711 \\
0.3048 & $\mathrm{ft}$ & $\mathrm{m}$ & 3.2808 \\
3.7854 & gal & $\mathrm{L}$ & 0.2642 \\
2.54 & inch(es) & $\mathrm{cm}$ & 0.3937 \\
25.4 & inch $(\mathrm{es})$ & $\mathrm{mm}$ & 0.0394 \\
6.4516 & inch & $\mathrm{cm}^{2}$ & 0.1550 \\
1.1209 & lb $/ \mathrm{acre}$ & $\mathrm{kg} \cdot \mathrm{ha}^{-1}$ & 0.8922 \\
28.3495 & $\mathrm{Oz}$ & $\mathrm{g}$ & 0.0353 \\
70.0532 & $\mathrm{Oz} / \mathrm{acre}$ & $\mathrm{g} \cdot \mathrm{ha}^{-1}$ & 0.0143 \\
6.8948 & $\mathrm{psi}$ & $\mathrm{kPa}$ & 0.1450 \\
$\left({ }^{\circ} \mathrm{F}-32\right) \div 1.8$ & ${ }^{\circ} \mathrm{F}$ & ${ }^{\circ} \mathrm{C}$ & $\left({ }^{\circ} \mathrm{C} \times 1.8\right)+32$
\end{tabular}


insecticide sprays to suppress sweetpotato whitefly populations in the field. However, large populations and the $\mathrm{CuLCrV}$ persistent-circulative mode of transmission, in which whiteflies may remain viruliferous throughout their entire life cycle, result in the reduced efficacy of spray programs to minimize the impact of CuLCrV (Dutta et al., 2019). Furthermore, sweetpotato whitefly resistance to insecticides has been reported for more than 60 active ingredients (Mota-Sanchez and Wise, 2019), including organophosphates, carbamates, pyrethroids, insect growth regulators, pyriproxyfen, buprofezin, neonicotinoids, ketoenols, diamides, and pymetrozine (Horowitz et al., 2020). Therefore, integrated pest management practices comprise an essential alternative to spray programs and have shown satisfactory results managing this pest. For example, the use of reflective mulches has been reported to reduce sweetpotato whitefly populations in a variety of crops (Csizinszky et al., 1999; Kousik et al., 2015; Nyoike et al., 2008; Polston and Lapidot, 2007; Simmons et al., 2010; Smith et al., 2000; Summers et al., 2004). In Georgia, $76 \%$ to $81 \%$ reductions in sweetpotato whitefly adults and nymphs were reported for tomato (Solanum lycopersicum) during a 3-year study using reflective silver mulch (Riley and Srinivasan, 2019). Additionally, biological controls (i.e., entomopathogenic fungi Beauveria bassiana, Paecilomyces fumosoroseus, and Clonostachys rosea) and organic insecticides have reportedly reduced sweetpotato whitefly populations ( $85 \%$ to $90 \%$ ) in cucumber, cantaloupe (Cucumis melo), zucchini, and yellow squash (Anwar et al., 2018; Wraight et al., 2000).
The aforementioned studies reported that cultivar selection is a key step in the implementation of an integrated pest management strategy for sweetpotato whitefly populations and the virus complex transmitted by them. However, there are no reports of yellow squash and zucchini resistance to $\mathrm{CuLCrV}$ available for commercial cultivars to date. Therefore, this study evaluated commercial cultivars of yellow squash and zucchini for resistance to whiteflies and $\mathrm{CuLCrV}$ and estimated yield and fruit quality under the environmental conditions of the southeastern United States.

\section{Materials and methods}

Field experiments were conducted at the Tifton Vegetable Park at the University of Georgia, Tifton, GA (lat. $31^{\circ} 29^{\prime} 14^{\prime \prime} \mathrm{N}$, long. $83^{\circ} 31^{\prime} 10^{\prime \prime} \mathrm{W}$ ). The soil is characterized as a Tifton loamy sand series (2\% slope) (U.S. Department of Agriculture, 1983). The climate in the region is classified as Cfa (humid subtropical climate) and is characterized by high temperatures with precipitation during the summer and cool dry periods during the winter (Köppen, 1931).

EXPERIMENTAL DESIGN AND CROP MANAGEMENT. Factorial experimental designs for nine yellow squash cultivars and 11 zucchini cultivars (Table 1) were separately arranged in a randomized complete block design $(\mathrm{r}=$ 3 ) during Fall 2017, Fall 2018, and Fall 2019. Seeds were directly planted on 18 Aug. 2017, 10 Aug. 2018, and 30 Aug. 2019, on 6-inch-tall raised beds spaced at $6 \mathrm{ft}$ center-to-center with white-on-black totally impermeable film (TIF) plastic mulch (Vaporsafe RM, 60-inch; Raven Industries, Sioux
Falls, SD). A single row of plants was spaced 12 inches apart within rows on each bed for a population of 7260 plants/acre or 17,939 plants/ha. Within each bed, experimental plots comprised 10 plants. Adjacent plots within a bed were separated by a 5 -ft buffer.

During all growing seasons, yellow squash and zucchini cultivars were sprayed weekly with $10 \mathrm{oz} /$ acre flupyradifurone (Sivanto 200 SL; Bayer CropScience, Research Triangle Park, NC), $8 \mathrm{oz}$ /acre fyriproxyfen (Knack; Valent, Walnut Creek, CA), or $15 \mathrm{oz} /$ acre cyantraniliprole (Exriel; DuPont, Wilmington, DE) to control sweetpotato whitefly. All other pest management practices used for disease control were performed according to the recommendations of the University of Georgia (Taylor, 2018). Fertilizer was applied weekly to supply $150 \mathrm{lb} /$ acre of nitrogen using $7 \mathrm{~N}-0 \mathrm{P}-5.8 \mathrm{~K}$ (Big Bend Supply Co., Cairo, GA) via fertigation. Irrigation water was applied daily through drip irrigation tubing (12-inch emitter spacing, $0.5 \mathrm{gal} / \mathrm{min}$ per $100 \mathrm{ft}$ at 10 psi; Chapin DLX; Jain USA, Haines City, FL) placed in the center of the bed. Irrigation events were applied to supply the historical crop evapotranspiration according to the methods of da Silva et al. (2019).

MONITORING OF WEATHER CONDITIONS AND THE SWEETPOTATO WHITEFLY POPULATION. Rainfall and maximum and minimum air temperatures were recorded hourly using an automated weather station located in Tifton, GA, provided by the Georgia Automated Environmental Monitoring Network (University of Georgia Weather Network, 2019).

In 2018 and 2019, sweetpotato whitefly populations were monitored

Table 1. Zucchini and yellow squash cultivars used during the field experiments conducted during the growing seasons of 2017,2018 , and 2019.

\begin{tabular}{llll}
\hline Zucchini cultivar & \multicolumn{1}{c}{ Reported resistance } & Yellow squash cultivar & Reported resistance \\
\hline SV6009 & Px, CMV, WMV, ZYMV & Lioness & PRSV, CMV, WMV, ZYMV \\
SV0914 & Pcu, SLCV, CMV, WMV, ZYMV & Grand Prize & Px, PRSV, WMV, ZYMV \\
SV0474 & Px, CMV, WMV, ZYMV & Gold Prize & WMV, ZYMV \\
Esteem & Px, PRSV, WMV, ZYMV & Conqueror III & PRSV, CMV, WMV, ZYMV \\
Payload & Px, PRSV, CMV, WMV, ZYMV & Enterprise & \\
Respect & Px, PRSV, WMV, ZYMV & Lazor & ZYMV \\
Justice III & CMV, WMV, ZYMV & Gold Star & Px, CMV \\
Paycheck & Px, CMV, WMV, ZYMV & Cosmos & PR, PRV, WMV, ZYMV \\
Spineless Beauty & & Gentry & - \\
Spineless Perfection & Px, WMV, ZYMV & & \\
Spineless King & Px, WMV, ZYMV & & \\
\hline
\end{tabular}

$\mathrm{Px}=$ powdery mildew caused by Podosphaera xanthii CMV = Cucumber mosaic virus; WMV = Watermelon mosaic virus; ZYMV = Zucchini yellow mosaic virus; Pcu = Pseudoperonospora cubensis; SLCV = Squash leaf curl virus; PRSV = Papaya ringspot virus. 


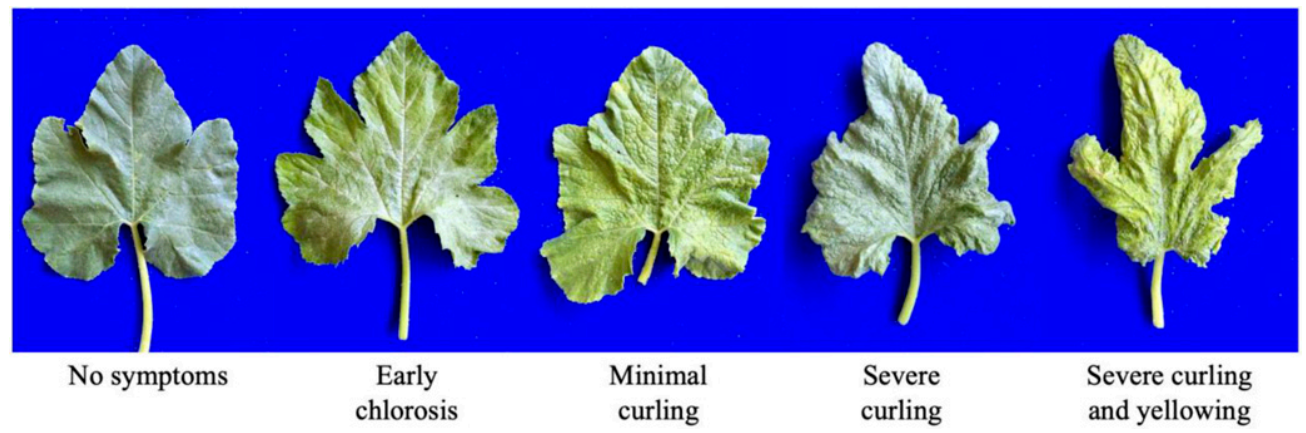

Fig. 1. Disease score criteria used for cucurbit leaf crumple virus $(\mathrm{CuLCrV})$ in yellow squash and zucchini. Scales: $1=$ no visible symptoms; $2=\leq \mathbf{5 0} \%$ of plants showing leaves with minimal curling symptoms and early chlorosis; $3=>50 \%$ of plants showing leaves with minimal curling and early chlorosis; $4=\leq 50 \%$ of plants showing leaves with severe curling, yellowing, or stunting; and $\mathbf{5}=>\mathbf{5 0} \%$ of plants showing severe curling, yellowing, or stunning.

weekly using yellow pest monitor cards (3- $\times 5$-inch sensor; BASF, Research Triangle Park, NC) during the entire year. Yellow pest monitor cards were installed $15 \mathrm{~cm}$ above the ground and vertically oriented. The numbers of whiteflies were counted in the center 12 inches ${ }^{2}$ of each card.

Monitoring of CuLCrV DURING GROWING SEASONS. During all growing seasons, yellow squash and zucchini plants were rated weekly for the severity of CuLCrV starting at first harvest (9 Sept. 2017, 11 Sept. 2018, and 22 Sept. 2019). The CuLCrV monitoring was conducted over 4 consecutive weeks. During each screening, an overall score was assigned to each plot of both trials using the severity ratings for $\mathrm{CuLCrV}$ (Fig. $\mathrm{l}$ ) as follows: 1 = no visible symptoms; $2=$ $\leq 50 \%$ of plants showing leaves with minimal curling symptoms and early chlorosis; $3=>50 \%$ of plants showing leaves with minimal curling and early chlorosis; $4=\leq 50 \%$ of plants showing leaves with severe curling, yellowing, or stunting; and $5=>50 \%$ of plants showing severe curling, yellowing, or stunning.

To confirm the CuLCrV symptoms on yellow squash and zucchini, leaf samples $(n=3$ samples per replicate per cultivar) were tested using a real-time polymerase chain reaction assay specific for $\mathrm{CuLCrV}$ (Gautam et al., 2020). DNA samples that tested positive for $\mathrm{CuLCrV}$ were included as a positive control. Water was added instead of DNA in negative controls.

Yellow SQUASH AND ZUCCHINI HARVEST. Yellow squash and zucchini plants were harvested three times weekly starting on 9 Sept. 2017, 11 Sept. 2018, and 22 Sept. 2019.
Harvests were conducted 12 times during each season and fruit were graded as fancy (US no. 1), medium, and cull fruit according to the U.S. Department of Agriculture grade standards (U.S. Department of Agriculture, 2016). For both yellow squash and zucchini, fruit classified as fancy had an average weight of $158 \mathrm{~g}$ and average length of $15 \mathrm{~cm}$, whereas fruit classified as medium had an average weight of $294 \mathrm{~g}$ and average length of $20 \mathrm{~cm}$. Fruit was culled (unmarketable) because of shape, virus symptoms, and poor color.

Statistical analysis. Statistical analyses were performed using the software JMP Pro 15.0 (SAS Institute, Cary, NC). For each crop, the severity of $\mathrm{CuLCrV}$ was analyzed using cultivar, sampling time, year, and their interactions as fixed effects, whereas sampling time was treated as a repeated measurement. The total yield and yield of fancy, medium, and cull fruit of yellow squash and zucchini were analyzed using cultivar, year, and their interaction as fixed effects. During all analyses, when the $F$ value of the analysis of variance was significant, multiple mean comparisons were performed using Tukey's test with a $P$ value of 0.05 . Additionally, the severity of $\mathrm{CuLCrV}$ at first harvest was correlated with yellow squash and zucchini yields of total fancy, medium, and cull fruit. Correlations were considered significant at a $P$ value of 0.05 , and the Pearson coefficient was selected to determine the strength of the correlation.

\section{Results}

WEATHER CONDITIONS AND SWEETPOTATO WHITEFLY POPULATIONS. Sweetpotato whitefly populations in
2018 and 2019 were negligible from January to June; they increased during July, August, and September, and they started to decline from October to December (Fig. 2). Sweetpotato whitefly populations comprised an average of 130 whitefly adults/trap on 21 Sept. 2018, and an average of 637 whitefly adults/trap on 20 Sept. 2019. During the yellow squash and zucchini growing seasons, sweetpotato whitefly trap counts were, on average, $25,98,76$, and 23 whitefly adults/trap in 2018, and 86, 450, 258 , and 170 whitefly adults/trap in 2019, during planting, vegetative growth, flowering, and fruiting/harvest stages, respectively.

Daily maximum and minimum air temperatures varied more during 2017 and 2019 than during 2018 (Fig. 3); however, daily maximum and minimum air temperatures during all study years were within the optimum range for sweetpotato whitefly development $\left(15\right.$ to $\left.35^{\circ} \mathrm{C}\right)$. The average daily air temperature for all years was $26^{\circ} \mathrm{C}$.

Rainfall accumulations during each season were 229,380 , and 58 $\mathrm{mm}$ in 2017, 2018, and 2019, respectively. The frequency of rainfall events seemed to affect sweetpotato whitefly populations more than the total volume of rainfall. In 2017, there were few scattered heavy rainfall events (Fig. 3), which led to extremely high levels of sweetpotato whitefly adults observed in the field (data not recorded). In 2018, rainfall occurred almost daily, early in the season (Fig. 2). Consequently, sweetpotato whitefly populations were the lowest in 2018 (Fig. 2). In 2019, there were scattered rain events during the study 


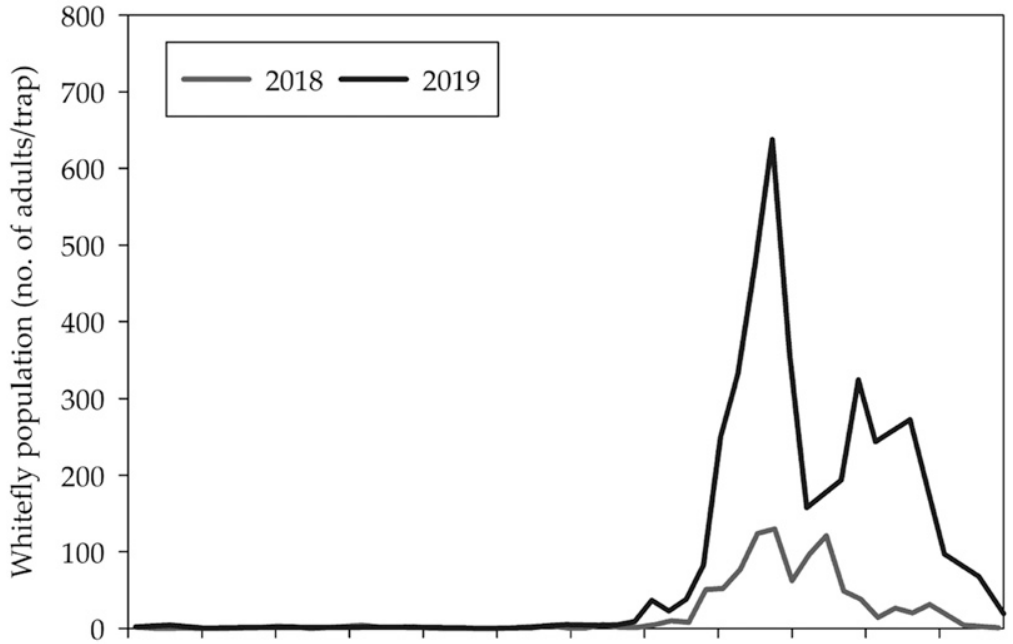

Jan. Feb. Mar. Apr. May Jun. Jul. Aug. Sep. Oct. Nov. Dec.

Months of year

Fig. 2. Sweetpotato whitefly population per trap (no. of adult whiteflies/12 inches $^{2}$ ) in 2018 and 2019, in Tifton, GA. 1 inch $=2.54 \mathrm{~cm}$.

period (Fig. 3), which may have resulted in higher sweetpotato whitefly populations (Fig. 2).

EFFects OF CuLCrV ON Yellow SQUASH AND ZUCCHINI. Year, sampling time, and cultivar did not significantly interact to affect $\mathrm{CuLCrV}$ severity in yellow squash. However, the main effect of year and cultivar significantly affected $\mathrm{CuLCrV}$ severity in yellow squash (Fig. 4). The mean severity of CuLCrV was highest in 2017 (4.3), followed by 2019 (3.2) and 2018 (0.1). Cultivars Cosmos (2.8) and Gold Star (2.8) had the highest CuLCrV severity ratings; however, their severity ratings were not significantly different from those of cultivars Conqueror III (2.6), Enterprise (2.5), Gentry (2.7), and Lazor (2.5). The cultivar Lioness (2.1) had the lowest CuLCrV severity.

Similar to yellow squash, significant interactions were not observed among years, sampling time, and cultivar for CuLCrV severity in zucchini. However, the main effects of year and cultivar were significant for $\mathrm{CuLCrV}$ severity (Fig. 5). The CuLCrV severity ratings were highest in 2017 and 2019. There were no visible $\mathrm{CuLCrV}$ symptoms observed in zucchini in 2018. For the main effect of cultivar, 'Paycheck' (1.9) had the highest severity rating for $\mathrm{CuLCrV}$, whereas 'Justice III' (1.3) had the lowest severity rating. The severity rating of 'Paycheck' was not significantly different from those of 'Spineless Beauty' (1.8), 'Spineless King' (1.7), 'Spineless Perfection' (1.8), and 'SV0474YG' (1.7).

Yellow SQUASH AND ZuCCHINI YIELD AND FRUIT QUALITY. There was a significant interaction between year and cultivar for the yield of fancy, medium, and cull fruit of yellow squash (Table 2). The yield of fancy yellow squash fruit was higher during 2018 than during 2017 and 2019, regardless of cultivar (Table 3). In 2017, the fancy fruit yield was the greatest for cultivars Lioness (3790 kg.ha ${ }^{-1}$ ) and Grand Prize $\left(3487 \mathrm{~kg} \cdot \mathrm{ha}^{-1}\right)$. Cultivar Gentry $\left(30,078 \mathrm{~kg} \cdot \mathrm{ha}^{-1}\right)$ had the highest yield of fancy fruit in 2018, whereas cultivars Gold Prize $\left(2684 \mathrm{~kg} \cdot \mathrm{ha}^{-1}\right)$, Grand Prize $\left(1554 \mathrm{~kg} \cdot \mathrm{ha}^{-1}\right)$, and Gold Star $\left(1018 \mathrm{~kg} \cdot \mathrm{ha}^{-1}\right)$ had the highest yield of fancy in 2019. The yield of medium

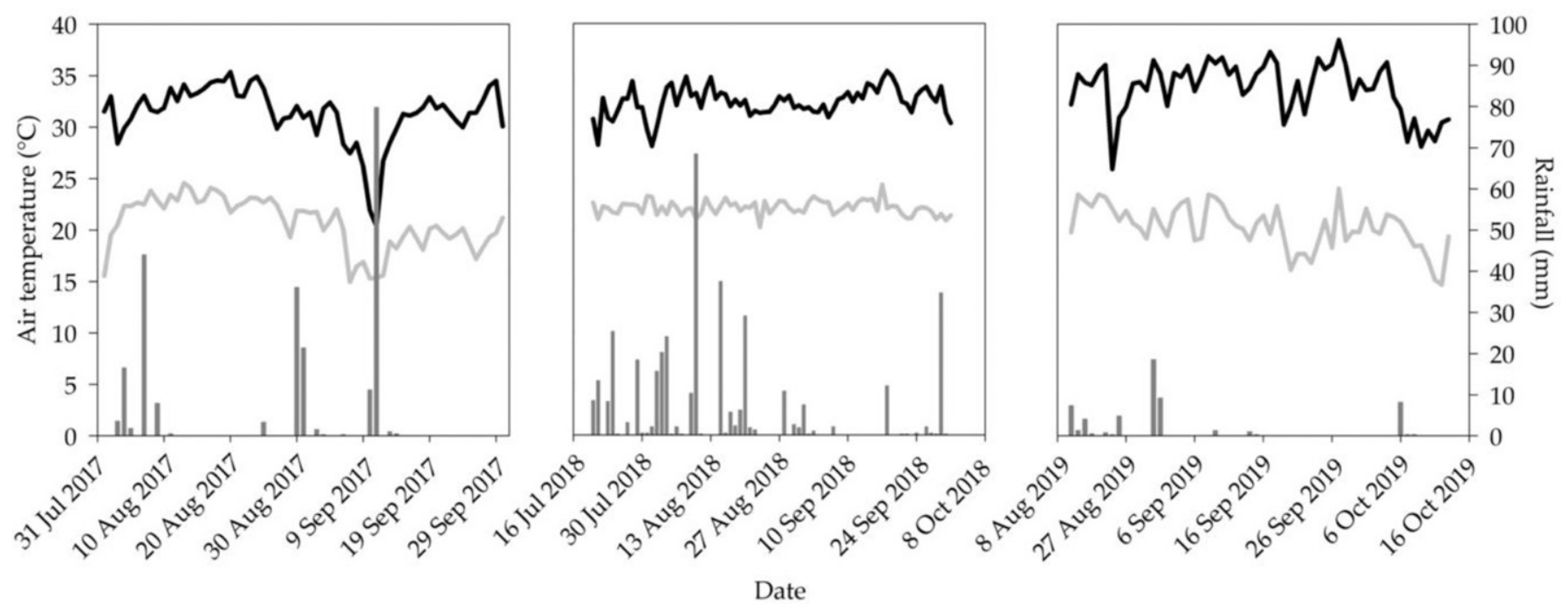

Rainfall — Maximum temperature $\longrightarrow$ Minimum temperature

Fig. 3. Weather conditions during 2017,2018 , and 2019 , including maximum and minimum air temperatures $\left({ }^{\circ} \mathrm{C}\right)$ and rainfall events $(\mathrm{mm})$. Data recorded at 1 -h intervals and retrieved from the Georgia Automated Environmental Monitoring Network at Tifton. Yellow squash and zucchini were planted on 8 Aug. 2017, 10 Aug. 2018, and 30 Aug. 2019, and harvested three times weekly for a total of 12 harvests starting on 9 Sept. 2017, 11 Sept. 2018, and 22 Sept. 2019. (1.8 $\times$ $\left.{ }^{\circ} \mathrm{C}\right)+32={ }^{\circ} \mathrm{F} ; \mathrm{l} \mathrm{mm}=0.0394$ inch. 

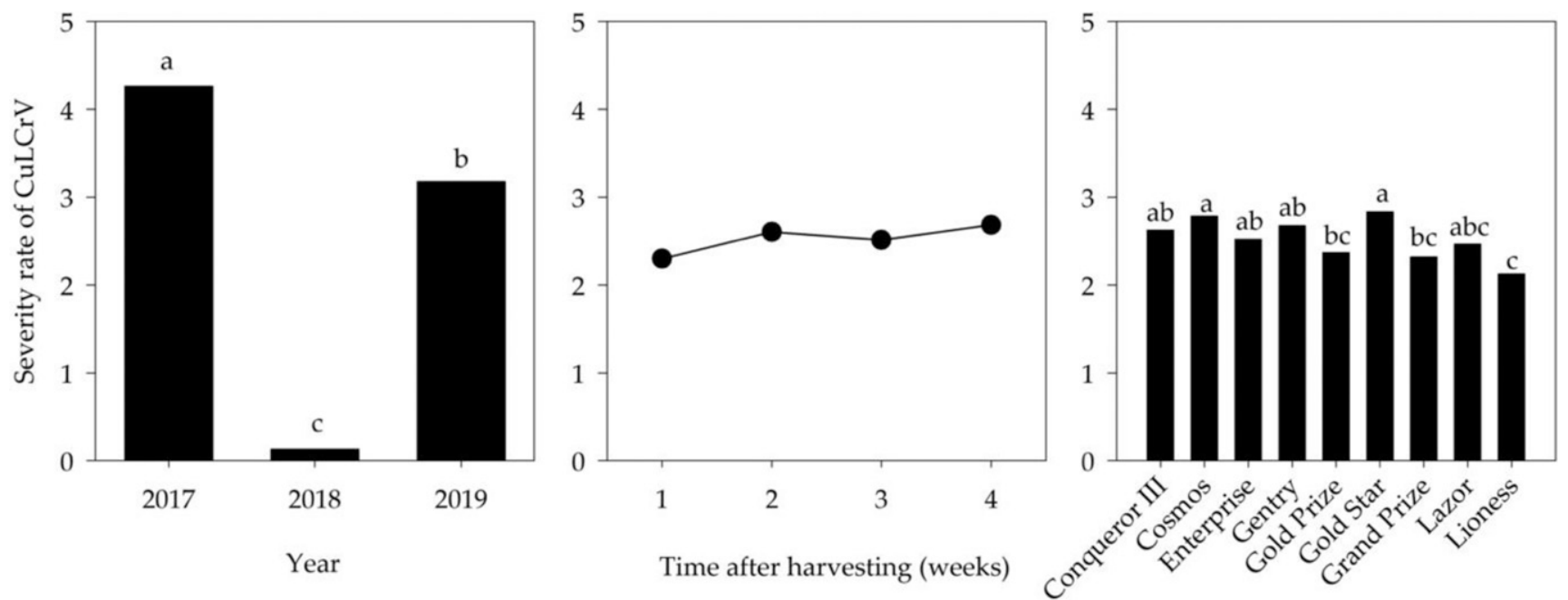

Fig. 4. The severity of cucurbit leaf crumple virus $(\mathrm{CuLCrV})$ per year, the week after the first harvesting, and among cultivars during the yellow squash development during 2017,2018 , and 2019 . Severity scales: $1=$ no visible symptoms; $2=\leq 50 \%$ of plants showing leaves with minimal curling symptoms and early chlorosis; $3=>50 \%$ of plants showing leaves with minimal curling and early chlorosis; $4=\leq \mathbf{5 0} \%$ of plants showing leaves with severe curling, yellowing, or stunting; and $\mathbf{5}=>\mathbf{5 0} \%$ of plants showing severe curling, yellowing, or stunning. Values followed by the same letters within each graphic indicate no significant difference $(P<0.05)$ according to the Tukey-Kramer adjustment.

fruit was higher in 2018 and 2019 than in 2017 for all cultivars, except for Cosmos, which had the highest yield of medium fruit only in 2018 . The cultivar had no effect on the yield of medium fruit in 2017 and 2018, whereas cultivar Gold Star (1283 $\mathrm{kg} \cdot \mathrm{ha}^{-1}$ ) had the highest yield of medium fruit in 2019. Yellow squash grown in 2018 had the highest yield of cull fruit; however, then number of cull fruit in 2017 was significantly higher than that in 2018. The lowest yield of cull fruit was measured in 2019; this might have been expected because the 2019 study year had the lowest total yield. The overall average numbers of cull fruit in 2017, 2018, and 2019 represented $89 \%, 46 \%$, and $26 \%$ of total yields, respectively.

Similar to yellow squash, zucchini fancy, medium, and cull yields were affected by a significant interaction between year and cultivar (Table 3 ). The yield of fancy zucchini fruit was not significantly different among years for all cultivars, except for Respect, which had a lower yield of fancy fruit in 2019 compared with 2018, and except for SV6009, which had a lower yield in 2019 compared with 2018 and 2017. In 2017, the cultivar SV6009 $\left(15,793 \mathrm{~kg} \cdot \mathrm{ha}^{-1}\right)$ had the highest yield

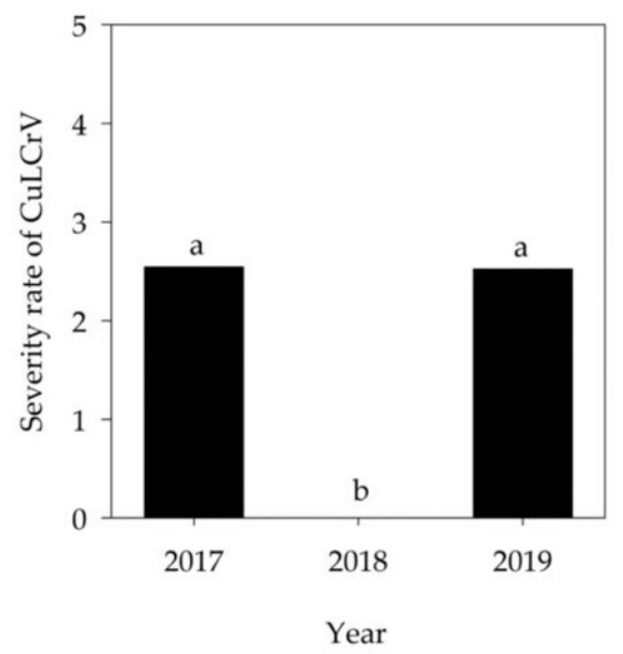

Year

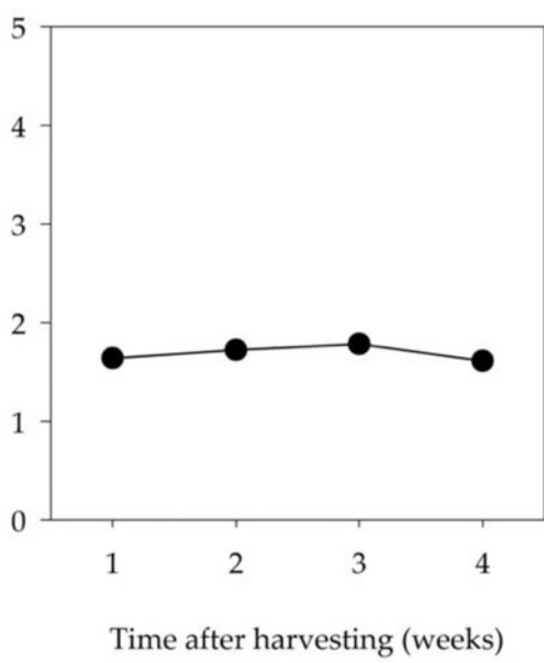

Fig. 5. The severity of cucurbit leaf crumple virus (CuLCrV) per year, the week after harvesting, and among cultivars during zucchini development during 2017,2018 , and 2019 . Severity scales: 1 = no visible symptoms; $2=\leq 50 \%$ of plants showing leaves with minimal curling symptoms and early chlorosis; $3=>50 \%$ of plants showing leaves with minimal curling and early chlorosis; $4=\leq \mathbf{5 0} \%$ of plants showing leaves with severe curling, yellowing, or stunting; and $\mathbf{5}=\mathbf{5 0} \%$ of plants showing severe curling, yellowing, or stunning. Values followed by the same letters within each graphic indicate no significant difference $(P<0.05)$ according to the Tukey-Kramer adjustment. 
Table 2. Effect of the interaction between yellow squash cultivar and year on the yield of fancy, medium, and cull fruit in Tifton, GA.

\begin{tabular}{|c|c|c|c|}
\hline \multirow[b]{3}{*}{ Yellow squash cultivar } & \multicolumn{3}{|c|}{ Yr } \\
\hline & 2017 & 2018 & 2019 \\
\hline & & Yield $\left(\mathrm{kg} \cdot \mathrm{ha}^{-1}\right)^{\mathrm{z}}$ & \\
\hline Conqueror III & $855 b^{y} B^{x}$ & 19,322 b A & $274 \mathrm{~b} \mathrm{~B}$ \\
\hline Cosmos & $0 \mathrm{c} \mathrm{B}$ & $18,288 \mathrm{~b} \mathrm{~A}$ & $0 \mathrm{~b} \mathrm{~B}$ \\
\hline Gold Prize & $960 \mathrm{~b} \mathrm{~B}$ & $16,521 \mathrm{~b} \mathrm{~A}$ & 2,684 a $\mathrm{B}$ \\
\hline Gold Star & $95 \mathrm{c} \mathrm{B}$ & $19,370 \mathrm{~b} \mathrm{~A}$ & 1,018 a $\mathrm{B}$ \\
\hline Grand Prize & 3,487 a $B$ & $13,530 \mathrm{~b} \mathrm{~A}$ & 1,554 a $B$ \\
\hline Lazor & 475 bc B & 19,718 b A & 329 b B \\
\hline Lioness & 3,790 a $\mathrm{B}$ & $11,542 \mathrm{~b} \mathrm{~A}$ & $493 \mathrm{~b} \mathrm{~B}$ \\
\hline Gentry & 0 a B & 1,254 a $\mathrm{A}$ & $256 \mathrm{~b} \mathrm{~A}$ \\
\hline Gold Prize & 0 a $\mathrm{B}$ & 868 a A & $250 \mathrm{~b} \mathrm{~A}$ \\
\hline Gold Star & 0 a $\mathrm{B}$ & 1,519 a $\mathrm{A}$ & 1,283 a $A$ \\
\hline Grand Prize & 0 a $\mathrm{B}$ & 109 a A & $438 \mathrm{ab} A$ \\
\hline Lazor & 0 a $\mathrm{B}$ & 217 a $\mathrm{A}$ & $313 \mathrm{ab} \mathrm{A}$ \\
\hline Lioness & 0 a B & 1,145 a $\mathrm{A}$ & $63 \mathrm{~b} \mathrm{~A}$ \\
\hline \multicolumn{4}{|c|}{ Cull fruit } \\
\hline Conqueror III & 9,495 bc B & 21,007 a $\mathrm{A}$ & 164 a $C$ \\
\hline Cosmos & 7,596 с B & $15,070 \mathrm{ab} A$ & 0 a $\mathrm{C}$ \\
\hline Enterprise & 9,970 abc $A$ & 16,848 a $\mathrm{A}$ & 169 a $B$ \\
\hline
\end{tabular}

of fancy fruit, whereas cultivar Spineless King (4093 $\mathrm{kg} \cdot \mathrm{ha}^{-1}$ ) had the lowest. There were no significant differences among any other cultivars for yields of fancy fruit in 2017. In 2018, the yield of fancy fruit was not different among cultivars. In 2019, cultivar SV0914 $\left(11,789 \mathrm{~kg} \cdot \mathrm{ha}^{-1}\right)$ had the highest yield of fancy fruit, whereas 'Justice III' (307l $\mathrm{kg} \cdot \mathrm{ha}^{-1}$ ), 'Respect' (2629 $\mathrm{kg} \cdot \mathrm{ha}^{-1}$ ), and 'Spineless King' (1986 $\mathrm{kg} \cdot \mathrm{ha}^{-1}$ ) had the lowest yields of fancy fruit. The yield of medium fruit was higher in 2018 and 2019 than in 2017 for all cultivars. In 2017 and 2018, there were no significant differences among cultivars for yields of medium fruit. In 2019, the cultivar Spineless King (7342 $\mathrm{kg} \cdot \mathrm{ha}^{-1}$ ) had a significantly greater yield of medium fruit than cultivars Spineless
Beauty, Esteem, and Justice III. In general, the yield of zucchini cull fruit was significantly greater in 2017 and 2018 than in 2019, except for cultivars Esteem, Respect, Spineless Beauty, and SV0474, which had no significant difference in yield of cull fruit across years. In 2017, cultivar Paycheck $\left(13,685 \mathrm{~kg} \cdot \mathrm{ha}^{-1}\right)$ had the highest yield of cull fruit, and cultivar Esteem $\left(6735 \mathrm{~kg} \cdot \mathrm{ha}^{-1}\right)$ the lowest. In 2018 and 2019 , there were no significant differences in cull fruit among cultivars. The highest yield of cull fruit was measured in 2017.

\section{EFFects of CuLCRV ON Yield} AND FRUIT QUALITY. The effect of $\mathrm{CuLCrV}$ on yellow squash and zucchini total yield and fruit quality are correlated in Figs. 6 and 7. The yellow squash total yield and yield of fancy, medium, and cull fruit significantly decreased with an increase in yellow squash CuLCrV severity (Fig. 6). Although the zucchini total yield and yield of fancy fruit were significantly and negatively correlated with $\mathrm{CuLCrV}$ severity (Fig. 7), there were no significant correlations between the yields of medium and cull fruit with $\mathrm{CuLCrV}$ severity for zucchini (Fig. 7).

\section{Discussion}

Weather conditions impacted sweetpotato whitefly populations during the 3 years when they were studied. Our results are supported by the literature, in which there is a generally positive correlation between sweetpotato whitefly populations and daily air 
Table 3. Effect of the interaction between zucchini cultivar and year on the yield of fancy fruit, medium fruit, and cull fruit in Tifton, GA.

\begin{tabular}{|c|c|c|c|}
\hline \multirow[b]{3}{*}{ Zucchini cultivar } & \multicolumn{3}{|c|}{$\mathbf{Y r}$} \\
\hline & 2017 & 2018 & 2019 \\
\hline & \multicolumn{3}{|c|}{ Yield $\left(\mathrm{kg} \cdot \mathrm{ha}^{-1}\right)^{\mathrm{z}}$} \\
\hline & \multicolumn{3}{|c|}{ Fancy fruit } \\
\hline Esteem & $10,456 a^{y} A^{x}$ & 12,744 a $\mathrm{A}$ & $4,916 \mathrm{ab} \mathrm{A}$ \\
\hline Justice III & $9,970 \mathrm{ab} A$ & 9,073 a $\mathrm{A}$ & $3,071 \mathrm{~b} \mathrm{~A}$ \\
\hline Paycheck & $14,521 \mathrm{ab} A$ & 8,688 a $A$ & $5,916 \mathrm{ab} A$ \\
\hline Payload & $10,339 \mathrm{ab} A$ & 16,257 a $\mathrm{A}$ & $6,532 \mathrm{ab} A$ \\
\hline Respect & $10,328 \mathrm{ab} \mathrm{AB}$ & 15,667 a $\mathrm{A}$ & 2,629 b B \\
\hline Spineless Beauty & $8,021 \mathrm{ab} A$ & 9,864 a $\mathrm{A}$ & $6,878 \mathrm{ab} \mathrm{A}$ \\
\hline Spineless King & $4,093 \mathrm{~b} \mathrm{~A}$ & 8,545 a $\mathrm{A}$ & $1,986 \mathrm{~b} \mathrm{~A}$ \\
\hline Spineless Perfection & $6,457 \mathrm{ab} \mathrm{A}$ & 9,709 a A & $8,986 \mathrm{ab} \mathrm{A}$ \\
\hline SV0474 & $8,118 \mathrm{ab} A$ & 17,905 a $\mathrm{A}$ & $9,078 \mathrm{ab} \mathrm{A}$ \\
\hline SV0914 & $11,254 \mathrm{ab} A$ & 15,761 a $\mathrm{A}$ & 11,789 a $\mathrm{A}$ \\
\hline \multirow[t]{2}{*}{ SV6009 } & 15,793 a A & 15,785 a A & $5,876 \mathrm{ab} \mathrm{B}$ \\
\hline & \multicolumn{3}{|c|}{ Medium fruit } \\
\hline Esteem & 310 a $B$ & 3,750 a $\mathrm{A}$ & $4,184 \mathrm{c} \mathrm{A}$ \\
\hline Justice III & 136 a B & 3,813 a $A$ & $3,484 \mathrm{c} \mathrm{A}$ \\
\hline Paycheck & 0 a B & 3,255 a $A$ & $4,820 \mathrm{abc} A$ \\
\hline Payload & 136 a B & 3,219 a A & $5,353 \mathrm{ab} \mathrm{A}$ \\
\hline Respect & 0 a B & 3,255 a $\mathrm{A}$ & $5,133 a b c A$ \\
\hline Spineless Beauty & 229 a B & 4,449 a $\mathrm{A}$ & $3,416 \mathrm{c} \mathrm{A}$ \\
\hline Spineless King & 0 a C & 2,496 a B & 7,342 a $\mathrm{A}$ \\
\hline Spineless Perfection & 109 a B & 3,445 a $\mathrm{A}$ & $2,696 \mathrm{c} \mathrm{A}$ \\
\hline SV0474 & 0 a B & 5,426 a $\mathrm{A}$ & $1,916 \mathrm{c} \mathrm{A}$ \\
\hline SV0914 & 362 a B & 4,967 a $\mathrm{A}$ & $3,063 \mathrm{c} \mathrm{A}$ \\
\hline \multirow[t]{2}{*}{ SV6009 } & 434 a B & 4,530 a $\mathrm{A}$ & 3,109 с A \\
\hline & \multicolumn{3}{|c|}{ Cull fruit } \\
\hline Esteem & $6,735 \mathrm{~b} \mathrm{~A}$ & 5,412 a $\mathrm{A}$ & 2,397 a A \\
\hline Justice III & $10,777 \mathrm{ab} \mathrm{A}$ & 6,791 a $A$ & 656 a B \\
\hline Paycheck & 13,685 a $\mathrm{A}$ & 6,093 a $B$ & $3,45 \mathrm{l}$ a $\mathrm{B}$ \\
\hline Payload & $12,699 \mathrm{ab} \mathrm{A}$ & 6,636 a $\mathrm{AB}$ & 3,145 a $B$ \\
\hline Respect & $8,777 \mathrm{ab} A$ & 5,127 a A & 3,177 a $\mathrm{A}$ \\
\hline Spineless Beauty & 7,629 ab A & 4,895 a $\mathrm{A}$ & 2,273 a $\mathrm{A}$ \\
\hline Spineless King & $10,571 \mathrm{ab} A$ & 7,691 a $A$ & 2,217 a $B$ \\
\hline Spineless Perfection & $7,881 \mathrm{ab} A$ & 7,121 a $A$ & 355 a $B$ \\
\hline SV0474 & $7,219 \mathrm{ab} A$ & 5,154 a $\mathrm{A}$ & 3,197 a A \\
\hline SV0914 & $9,956 \mathrm{ab} A$ & 8,461 a $A$ & 466 a B \\
\hline SV6009 & $10,033 \mathrm{ab} \mathrm{A}$ & 6,100 a $\mathrm{AB}$ & 2,041 a B \\
\hline
\end{tabular}

${ }^{\mathrm{z}} \mathrm{l} \mathrm{kg} \cdot \mathrm{ha}^{-1}=0.8922 \mathrm{lb} / \mathrm{acre}$.

${ }^{y}$ Within a column, values followed by the same lowercase letter indicate no significant difference $(P \leq 0.05)$ between cultivars according to the Tukey-Kramer adjustment.

${ }^{x}$ Within a row, values followed by the same uppercase letter indicate no significant difference $(P \leq 0.05)$ between years according to the Tukey-Kramer adjustment.

temperatures, and a negative correlation between sweetpotato whitefly populations and rainfall distribution (Hagen et al., 2008; Rafiq et al., 2008; Thriveni, 2019; Yadav et al., 2015). Although temperatures during all years were ideal for sweetpotato whitefly development, the few rainfall events during the early stages of yellow squash and zucchini development in 2017 and 2019 created optimum environmental conditions for sweetpotato whitefly reproduction (Yadav et al., 2015). In contrast, the frequent rainfall events in 2018 negatively impacted the sweetpotato whitefly populations during the same period.

Cultivar selection would be the first step of an integrated pest management strategy for the management of $\mathrm{CuLCrV}$ in yellow squash and zucchini. Although there were differences in yield among cultivars, $\mathrm{CuLCrV}$ symptoms were recorded for all yellow squash and zucchini cultivars evaluated. This suggests that resistance to $\mathrm{CuLCrV}$ in commercial yellow squash and zucchini are not available, particularly among the cultivars screened during this study. For yellow squash, the cultivar Lioness had the lowest severity rating of $\mathrm{CuLCrV}$, whereas cultivars Cosmos and Gold Star had the highest CuLCrV severity ratings. For zucchini, the cultivar Justice III had the lowest CuLCrV severity rating, whereas cultivar Paycheck the highest. The better performance of broad virus resistance packages to protect yields is commonly discussed for cultivar selection in an integrated pest management practice (Schultheis and Walters, 1998; Sikora et al., 2008). 


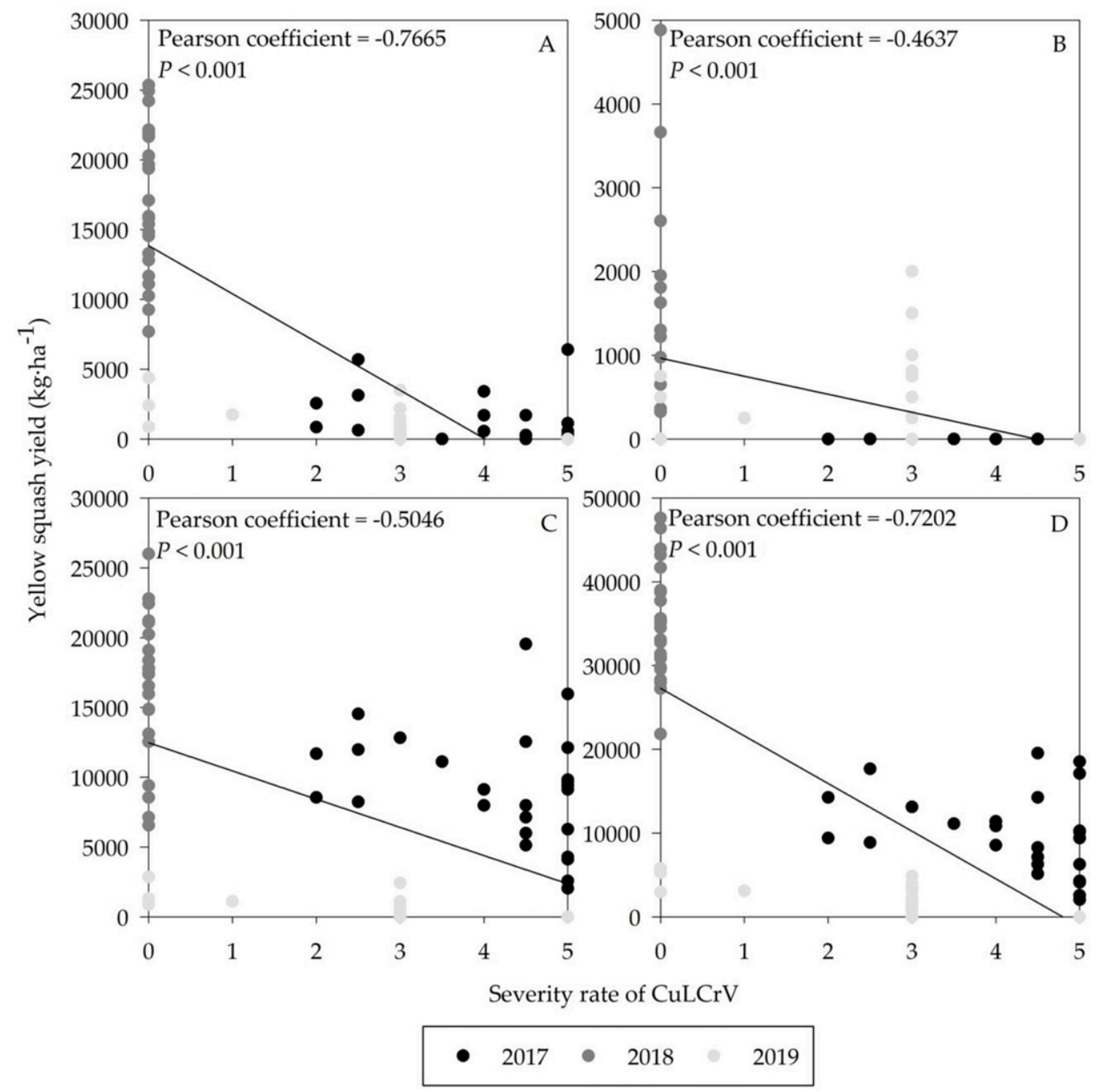

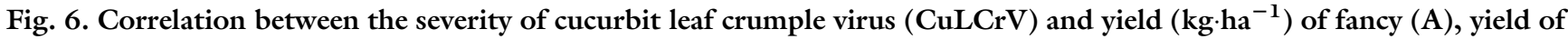
medium (B), yield of cull fruit (C), and total yield (D) during the 2017, 2018, and 2019 yellow squash seasons in Tifton, GA. $1 \mathrm{~kg} \cdot \mathrm{ha}^{-1}=0.8922 \mathrm{lb} /$ acre.

However, our results indicated that there is no consistent difference in virus resistance among the materials evaluated, thereby indicating that a broad virus resistance package does not necessarily guarantee resistance to all viruses.

Total yield and fruit quality for both crops were directly negatively correlated with CuLCrV severity, and similar results for yellow squash and zucchini have been previously reported (Adkins et al., 2011; Akad et al., 2008; Costa et al., 1994; McAvoy, 2017; Sikora et al., 2008; Webb et al., 2017). During our study, a CuLCrV severity rating higher than 3 led to very low yields, regardless of the crop. There was a stronger negative correlation among CuLCrV and total yield and quality parameters of yellow squash compared with that of zucchini, suggesting that yellow squash is more sensitive to sweetpotato whitefly and/or sweetpotato whitefly-transmitted viruses than zucchini. Particularly, the yellow squash cultivar Gentry had the highest yields when the sweetpotato whitefly populations were lower (i.e., 2018), but the yields were lower than those of other cultivars under high sweetpotato whitefly pressure (i.e., 2017 and 2019) when cultivars Lioness, Gold Prize, and Grand Prize had the highest yields. Similarly, zucchini cultivars SV6009 and SV0914 performed better than other cultivars under high sweetpotato whitefly populations (i.e., 2017 and 2019), but there was no significant difference among zucchini cultivars for yield when the sweetpotato whitefly pressure was low (i.e., 2018). These results corroborate those of Coolong (2017) and Rowell et al. (2002), who stated that yellow squash and zucchini cultivars with low or no virus resistance could achieve the same level of productivity and fruit quality in a disease-free environment.

\section{Conclusions}

Sweetpotato whitefly and sweetpotato whitefly-transmitted virus complex, particularly $\mathrm{CuLCrV}$, have become a major problem for yellow squash and zucchini production areas in the southeastern United States. Cultivar selection is the first step of the integrated pest management practice to minimize the impact of whiteflies on these crops; however, no available study has evaluated the resistance of commercial yellow squash and zucchini cultivars to CuLCrV. The present study evaluated commercial cultivars of yellow squash and zucchini for resistance to sweetpotato whitefly and against $\mathrm{CuLCrV}$ to determine yield and fruit quality under environmental 


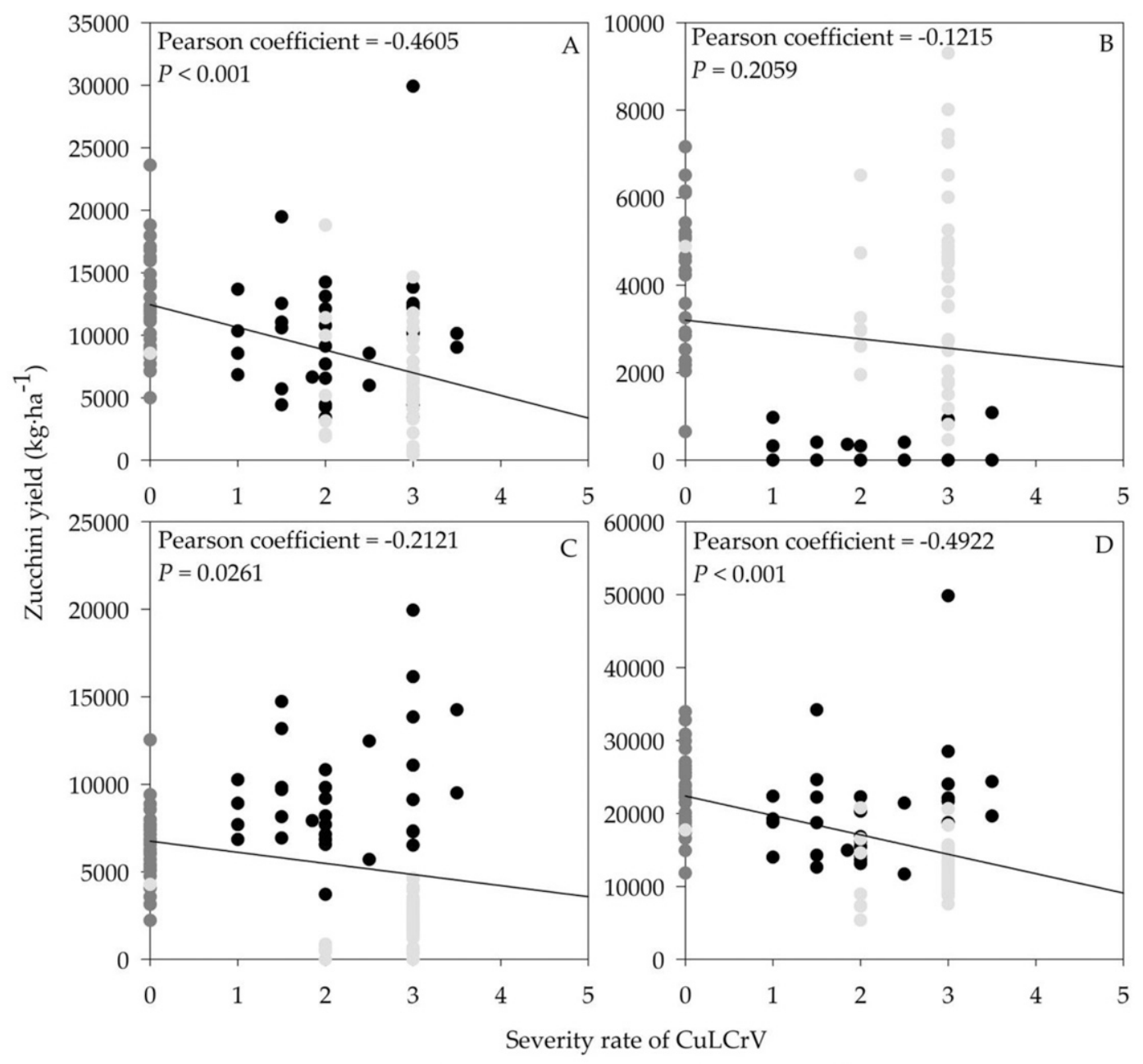

- $2017 \bullet 2018 \odot 2019$

Fig. 7. Correlation between the severity of cucurbit leaf crumple virus (CuLCrV) and yield $\left(\mathrm{kg} \cdot \mathrm{ha}^{-1}\right)$ of fancy (A), yield of medium (B), yield of cull fruit (C), and total yield (D) during the 2017, 2018, and 2019 zucchini seasons in Tifton, GA. 1 $\mathrm{kg} \cdot \mathrm{ha}^{-1}=0.8922 \mathrm{lb} / \mathrm{acre}$.

conditions of the southeastern United States. The sweetpotato whitefly population varied across years and was negatively correlated with the incidence of rainfall. The severity of $\mathrm{CuLCrV}$ negatively impacted the yield and quality of fruit of yellow squash and zucchini, and no resistant cultivar of yellow squash or zucchini was identified. Yellow squash cultivars Lioness, Gold Prize and Grand Prize, and zucchini cultivars SV6009 and SV0914 had the best yields under the highest sweetpotato whitefly population evaluated. In addition to cultivar recommendations, the information generated during this study can be useful for yield and loss estimates under different sweetpotato whitefly populations. Future studies should focus on evaluating alternative crop management practices (e.g., the effect of planting date to account for the impact of weather variability on the interaction between sweetpotato whitefly and crop development) that could be incorporated in integrated pest management for sweetpotato whitefly and sweetpotato whitefly-transmitted viruses.

\section{Literature Cited}

Adkins, S., C.G. Webster, C.S. Kousik, S.E. Webb, P.D. Roberts, P.A. Stansly, and W.W. Turechek. 2011. Ecology and management of whitefly-transmitted viruses of vegetable crops in Florida. Virus Res. 159: 110-114, doi: https://doi.org/10.1016/ j.virusres.2011.04.016.

Akad, F., S. Webb, W. Nyoike, O.E. Liburd, W. Turechek, S. Adkins, and J.E. Polston. 2008. Detection of cucurbit leaf crumple virus in Florida cucurbits. Plant Dis. 92:648, doi: https://doi.org/10.1094/PDIS-92-40648C.

Anwar, W., S. Ali, K. Nawaz, S. Iftikhar, M.A. Javed, A. Hashem, A.A. Alqarawi, E.F. Abd Allah, and A. Akhter. 2018. Entomopathogenic fungus Clonostachys rosea as a biocontrol agent against whitefly (Bemisia tabaci). Biocontrol Sci. Technol. 28:750-760, doi: https://doi.org/10. 1080/09583157.2018.1487030.

Coolong, T. 2017. Yellow squash and zucchini cultivar evaluation in Georgia. HortTechnology 27:296-302, doi: https://doi. org/10.21273/HORTTECH03605-16.

Costa, H.S., M.W. Johnson, and D.E. Ullman. 1994. Row covers effect on sweetpotato whitefly (Homoptera: Aleyrodidae) densities, incidence of silverleaf, and crop yield in zucchini. J. Econ. Entomol. 87: 1616-1621, doi: https://doi.org/10. 1093/jee/87.6.1616. 
Csizinszky, A., D.J. Schuster, and J.E. Polston. 1999. Effect of UV-reflective mulches on tomato yields and on the silverleaf whitefly. HortScience 34:911-914, doi: https:// doi.org/10.21273/HORTSCI.31.4.570a.

da Silva, A.L.B.R., T. Coolong, and E. Smith. 2019. Irrigating app. <https:// irrigating.uga.edu $>$.

Dutta, B., B. Myers, T. Coolong, B. Srinivasan, and A. Sparks. 2019. Whitefly-transmitted plant viruses in southern Georgia. Univ. Georgia Coop. Ext. Serv. Bul. 1507. $<$ https://secure.caes.uga.edu/extension/ publications/files/pdf/B\%201507_2.PDF>.

Gautam, D., M.S. Crossley, B. Dutta, T. Coolong, A.M. Simmons, A.L.B.R. da Silva, W.E. Snyder, and R. Srinivasan. 2020. Low genetic variability in Bemisia tabaci MEAMl populations within farmscapes of Georgia, USA. Insects 11:834, doi: https://doi.org/ 10.3390 /insects11120834.

Hagen, C., M.R. Rojas, T. Kon, and R.L. Gilbertson. 2008. Recovery from cucurbit leaf crumple virus (family Geminiviridae, genus Begomovirus) infection is an adaptive antiviral response associated with changes in viral small RNAs. Phytopathology 98:1029-1037, doi: https://doi. org/10.1094/PHYTO-98-9-1029.

Horowitz, R., M. Ghanim, E. Roditakis, R. Nauen, and I. Ishaaya. 2020. Insecticide resistance, and its management in Bemisia tabaci species. J. Pest Sci. 93: 893-910, doi: https://doi.org/10.1007/ s10340-020-01210-0.

Köppen, W. 1931. Grundriss der Klimakunde. Walter de Gruyter, Berlin, Germany.

Kousik, C.S., S. Adkins, C.G. Webster, W.W. Turechek, P. Stansly, and P.D. Roberts. 2015. Influence of insecticides and reflective mulch on watermelon vine decline caused by Squash vein yellowing virus (SqVYV). Plant Health Res. 16: 43-49, doi: https://doi.org/10.1094/ PHP-RS-14-0040.

Little, E.L. 2019. Georgia plant disease loss estimates 2016. Univ. Georgia Coop. Ext. Serv. Bull. AP 102-9. <https://secure. caes.uga.edu/extension/publications/files/ pdf/AP\%20102-9_1.PDF>.

McAvoy, G. 2017. Take caution to curb cucurbit leaf crumple virus. Growing Produce. 14 Feb. 2020. <https://www. growingproduce.com/crop-protection/ disease-control/take-caution-to-curbcucurbit-leaf-crumple-virus $/>$.

Mota-Sanchez, D. and J.C. Wise. 2019. The arthropod pesticide resistance database. Michigan State University. 23 Aug. 2020. $<$ http://www.pesticideresistance.org $>$.

Nyoike, T.W., O.E. Liburd, and S.E. Webb. 2008. Suppression of whiteflies,
Bemisia tabaci (Hemiptera: Aleyrodidae), and incidence of cucurbit leaf crumple virus, a whitefly-transmitted virus of zucchini squash new to Florida, with mulches and imidacloprid. Fla. Entomol. 91:460-465, doi: https://doi.org/10.1653/00154040(2008)91[460:SOWBTH]2.0.CO;2.

Polston, J.E. and M. Lapidot. 2007. Management of Tomato yellow leaf curl virus: US and Israel perspectives, p. 251-262. In: H. Czosnek (ed.). Tomato yellow leaf curl disease. Springer, Dordrecht, Netherlands.

Price, J.F., D.J. Schuster, and D.E. Short. 1987. Managing sweetpotato whitefly. Greenhouse Grower 35(12):55-57.

Rafiq, M., A. Ghaffar, and M. Arshad. 2008. Population dynamics of whitefly (Bemisia tabaci) on cultivated crop hosts and their role in regulating its carry-over to cotton. Intl. J. Agr. Biol. 10:577-580.

Riley, D.G. and R. Srinivasan. 2019. Integrated management of tomato yellow leaf curl virus and its whitefly vector in tomato. J. Econ. Entomol. 112:1526-1540, doi: https://doi.org/10.1093/jee/toz051.

Rowell, B., W. Nesmith, A. Satanek, and D. Slone. 2002. Yield and powdery mildew resistance of fall-harvested summer squash. Fruit Veg. Res. Rpt. Univ. Kentucky Coop. Ext. Serv. Bull. PR-470.

Schultheis, J.R. and S.A. Walters. 1998. Yield and virus resistance of summer squash cultivars and breeding lines in North Carolina. HortTechnology 8:31-39, doi: https://doi. org/10.21273/HORTTECH.8.1.31.

Sikora, E.J., J.F. Murphy, and J. Burkett. 2008. Performance of virus resistant transgenic yellow summer squash in Alabama. J. Veg. Sci. 12:75-83, doi: https://doi. org/10.1300/J484v12n02_07.

Simmons, A.M., C.S. Kousik, and A. Levi. 2010. Combining reflective mulch and host plant resistance for sweetpotato whitefly (Hemiptera: Aleyrodidae) management in watermelon. Crop Prot. 29:898-902, doi: https://doi.org/10.1016/j.cropro. 2010.04.003.

Smith, H.E., R.L. Koenig, H.J. McAuslane, and R. McSorley. 2000. Effect of silver reflective mulch and a summer squash trap crop on densities of immature Bemisia argentifolii (Homoptera: Aleyrodidae) on organic bean. J. Econ. Entomol. 93:726731, doi: https://doi.org/10.1603/ 0022-0493-93.3.726.

Summers, C.G., J.P. Mitchell, and J.J. Stapleton. 2004. Management of aphidborne viruses and Bemisia argentifolii (Homoptera: Aleyrodidae) in zucchini squash by using UV reflective plastic and wheat straw mulches. Environ. Entomol.
33:1447-1457, doi: https://doi.org/ 10.1603/0046-225X-33.5.1447.

Taylor, M.D. 2018. Georgia pest management handbook. Univ. Georgia Coop. Ext. Serv. Bull. 28. <https://extension.uga. edu/content/dam/extension/programsand-services/integrated-pest-management/ documents/handbooks/2021-pmh-commchapters/Vegetables.pdf $>$.

Thriveni, K.P. 2019. Correlation of whitefly population with weather parameters and management of leaf curl of chilli. J. Pharmacogn. Phytochem. 8:4624-4628.

U.S. Department of Agriculture. 1983. Soil survey. Web soil survey - Soil survey of Tift County, Georgia. 23 Aug. 2020. $<$ https://websoilsurvey.sc.egov.usda. gov/App/WebSoilSurvey.aspx $>$.

U.S. Department of Agriculture. 2016. United States standards for grades summer squash. U.S. Dept. Agr., Washington, DC. 14 Sept. 2020. <https://www.ams. usda.gov/grades-standards/summer-squashgrades-and-standards $>$.

U.S. Department of Agriculture. 2019. National Agricultural Statistics Service. Quick Stats. 16 Sept. 2019. <https:// quickstats.nass.usda.gov/>.

University of Georgia Weather Network. 2019. Tifton, Georgia climate data. 3 Dec. 2020. <http://www.georgiaweather.net/ index.php? content $=\mathrm{c} \% 20 \mathrm{a} \% 201 \% 20 \mathrm{c} \% 20 \mathrm{u} \%$ 20lator $\&$ variable $=C C \&$ site $=$ TIFTON $>$.

Webb, S.E., O.E. Liburd, T.W. Nyoike, F. Akad, and J.E. Polston. 2017. Whitefly-transmitted Cucurbit leaf crumple virus in Florida. Univ. Florida IFAS Ext. ENY477. 1-3. <https://edis.ifas.ufl.edu/ pdffiles/IN/IN71600.pdf $>$.

Wolfe, K. and K. Stubbs. 2018. Georgia farm gate value report 2017. Univ. Georgia Coop. Ext. Serv. Bull. AR-18-01. <https://caed.uga.edu/content/dam/ caes-subsite/caed/publications/annualreports-farm-gate-value-reports/2017farm-gate-value-report.pdf $>$.

Wraight, S.P., R.I. Carruthers, S.T. Jaronski, C.A. Bradley, C.J. Garza, and S. GalainiWraight. 2000. Evaluation of the entomopathogenic fungi Beauveria bassiana and Paecilomyces fumosoroseus for microbial control of the silverleaf whitefly, Bemisia argentifolii. Biol. Control 17:203-217, doi: https:// doi.org/10.1006/bcon.1999.0799.

Yadav, S.K., A.K. Yadav, R. Sanp, and H.L. Deshwal. 2015. Population of major sucking pests of cluster bean [Cyamopsis tetragonoloba (L.) Taub.] and their correlation with abiotic factors. Ann. Plant Prot. Sci. 24:31-33. 